Check for updates

New York

Cite this as: BMJ 2021;375:n3161 http://dx.doi.org/10.1136/bmj.n3161 Published: 30 December 2021

\title{
Covid-19: CDC shortens isolation period as US cases hit record high
}

\section{Janice Hopkins Tanne}

US cases of covid-19 hit a record daily average of 265 ooo cases on 28 December, the highest number since the pandemic began two years ago, according to Johns Hopkins University. ${ }^{1}$ There were about 1.8 million cases last week, a $69 \%$ increase over the week before.

The news site Politico reported a daily total of 441 278 new infections on 28 December, but the Centers for Disease Control and Prevention said it was an overestimate due to slow state reporting. ${ }^{2}$ The CDC said that covid-19 cases and hospital admissions have been increasing in recent weeks because of substantial or high levels of community transmission in many areas, the continuing spread of the delta variant, and the fast growing spread of the omicron variant. ${ }^{3}$ The agency estimated that the omicron variant was causing about $58.6 \%$ of new cases as of 25 December. $^{4}$

Ashish Jha, dean of Brown University School of Public Health, told CNN that "January is going to be a really, really hard month. And people should just brace themselves for a month where lots of people are going to get infected." ${ }^{5}$ An increasing number of children are being infected and admitted to hospital. Children aged 5 and older can be vaccinated but the numbers are low. Of the US population of about 330 million, some $71 \%$ of those aged 12 and above and $88 \%$ of those 65 and older have been fully vaccinated. ${ }^{6}$

Infections, hospital admissions, and deaths are sharply increasing in Washington, DC, New York, New Jersey, and Rhode Island, and in Puerto Rico. ${ }^{6}$ Infections are highest among unvaccinated people.

\section{Shorter isolation}

In view of the growing number of cases, the CDC has shortened its rules for isolation, quarantine, and mask wearing for healthcare workers and the public. It said that people who have covid-19 should isolate for five days, and if they are asymptomatic or if their symptoms are resolving (without fever for 24 hours), they should then wear a mask for five days when around others to minimise the risk of spreading the infection.

The agency said that the change was "motivated by science demonstrating that the majority of cases of SARS-CoV-2 transmission occurs early in the case of the illness, generally in the 1-2 days prior to onset of symptoms and the 2-3 days after." 7

The Washington Post said the decision was driven by concern that the number of infections would hamper essential services. Top health officials were "worried the sheer volume of infections could mean that tens of thousands of police, firefighters, grocery workers, and other essential employees would be out of work, making it challenging to keep society functioning, even though many of the infections would be mild or produce no symptoms," it said. ${ }^{8}$

The CDC also changed its advice for people exposed to covid-19. Anyone who is unvaccinated or received their second dose of mRNA vaccine more than six months ago (or Johnson \& Johnson vaccine more than two months ago) and has not received a booster shot should quarantine for five days followed by strict mask wearing for another five days. If a five day quarantine is not feasible, the person should wear a well fitting mask for 10 days when around other people. People are advised to get at covid-19 test five days after exposure. Those who develop symptoms are told to quarantine until a negative test shows they were not exposed to the virus.

Eric Topol of the Scripps Research Translational Institute told the Associated Press, "It's frankly reckless to proceed like this. Using a rapid test or some type of test to validate that the person isn't infectious is vital." "Yonatan Grad of Harvard's TH Chan School of Public Health told the New York Times, "to me this feels honestly more about economics than about science." 10

Healthcare workers who tested positive were previously told to stay home for 10 days. The new rules say they can return to work after seven days if they have a negative test and no symptoms. The CDC said that the isolation time could be reduced to five days or less if there were severe staffing shortages.

CDC director Rochelle Walensky said the updated recommendations "balance what we know about the spread of the virus and the protection provided by vaccination and booster doses. These updates ensure people can safely continue their daily lives."

Business leaders have approved the decision to reduce staff shortages. Criticism has come from a nursing organisation and a flight attendants group, who said the new rules would lead to increased infections from people forced to work while they were sick. $^{8}$

Johns Hopkins University. Coronavirus resource center. Tracking home. 29 Dec 2021. https://coronavirus.jhu.edu/map.html

2 Leonard B. US sets new daily high for covid cases. Politico. 28 Dec 2021. https://www.politico.com/news/2021/12/28/us-new-daily-high-covid526223

3 Centers for Disease Control and Prevention. Covid 19. Covid data tracker weekly review. 17 Dec 2021. https://www.cdc.gov/coronavirus/2019ncov/covid-data/covidview/index.html

4 Centers for Disease Control and Prevention. Covid data tracker. Variant proportions. https://covid.cdc.gov/covid-data-tracker/\#nowcast-heading

5 Yan H, Vera A. The US just hit a record average of daily new covid-19 cases. CNN.com. 29 Dec 202l. https://www.cnn.com/2021/12/28/us/us-coronavirus-tuesday/index.html.

6 New York Times. Coronavirus in the US: Latest map and case count. 29 Dec 2021. https://www.nytimes.com/interactive/2021/us/covid-cases.html Centers for Disease Control and Prevention. CDC updates and shortens recommended isolation and quarantine period for general population (press release). 27 Dec 2021. https://www.cdc.gov/media/releases/2021/s1227isolation-quarantine-guidance.html 
8 Abutaleb Y, Sullivan W, Rosenberg E. New CDC guidelines were spurred by worries omicron surge could lead to breakdown in essential services. Washington Post 28 Dec 2021.

https://www.washingtonpost.com/health/2021/12/28/cdc-isolation-guidelines-rationale/

9 Miller Z, Foody K. US move to shorten covid-19 isolation stirs confusion, doubt. The Associated Press. 28 Dec 2021. https://apnews.com/article/coronavirus-pandemic-business-health-centersfor-disease-control-and-prevention-6d74e88d73ab2443298b1f3f827a556f

10 Mueller B. Will shortened isolation periods spread the virus? New York Times 29 Dec 2021. https://www.nytimes.com/2021/12/28/health/covid-isolation-period-omicron.html

This article is made freely available for personal use in accordance with BMJ's website terms and conditions for the duration of the covid-19 pandemic or until otherwise determined by BMJ. You may download and print the article for any lawful, non-commercial purpose (including text and data mining) provided that all copyright notices and trade marks are retained. 